Corrected: Publisher correction

ARTICLE

Received 2 Aug 2016 | Accepted 12 Apr 2017 | Published 6 Jun $2017 \quad$ DOI: 10.1038/ncomms15659

\title{
Lithospheric foundering and underthrusting imaged beneath Tibet
}

Min Chen ${ }^{1}$, Fenglin Niu ${ }^{1,2}$, Jeroen Tromp ${ }^{3,4}$, Adrian Lenardic ${ }^{1}$, Cin-Ty A. Lee ${ }^{1}$, Wenrong Cao ${ }^{1} \&$ Julia Ribeiro $^{1}$

Long-standing debates exist over the timing and mechanism of uplift of the Tibetan Plateau and, more specifically, over the connection between lithospheric evolution and surface expressions of plateau uplift and volcanism. Here we show a T-shaped high wave speed structure in our new tomographic model beneath South-Central Tibet, interpreted as an upper-mantle remnant from earlier lithospheric foundering. Its spatial correlation with ultrapotassic and adakitic magmatism supports the hypothesis of convective removal of thickened Tibetan lithosphere causing major uplift of Southern Tibet during the Oligocene. Lithospheric foundering induces an asthenospheric drag force, which drives continued underthrusting of the Indian continental lithosphere and shortening and thickening of the Northern Tibetan lithosphere. Surface uplift of Northern Tibet is subject to more recent asthenospheric upwelling and thermal erosion of thickened lithosphere, which is spatially consistent with recent potassic volcanism and an imaged narrow low wave speed zone in the uppermost mantle.

\footnotetext{
${ }^{1} 318$ Keith-Wiess Geology Lab, Department of Earth Science, Rice University, MS 126, 6100 Main Street, Houston, Texas 77005, USA. ${ }^{2}$ State Key Laboratory of Petroleum Resource and Prospecting, and Unconventional Natural Gas Institute, China University of Petroleum, Beijing 102249, China. ${ }^{3}$ Department of Geosciences, Princeton University, Princeton, New Jersey 08544, USA. ${ }^{4}$ Program in Applied and Computational Mathematics, Princeton University, Princeton, New Jersey 08544, USA. Correspondence and requests for materials should be addressed to M.C. (email: Min.Chen@rice.edu).
} 
S ince the onset of 'hard' continent-continent collision at about $45 \mathrm{Ma}^{1}$, India-Eurasia convergence has produced the highly elevated Tibetan Plateau and Himalayan Mountain Belt. Geodetic observations suggest not only inter-plate convergence between India and Eurasia, but also intra-plate deformation within Tibet at present ${ }^{2,3}$. Measurements based on the Global Positioning System indicate that current crustal motion relative to stable Eurasia decreases northwards, with rates of $\sim 40 \mathrm{~mm}$ per year at Northern India, $\sim 25 \mathrm{~mm}$ per year at Central Tibet and $\sim 10 \mathrm{~mm}$ per year at Northern Tibet ${ }^{2}$ (Fig. 1), and an ongoing convergence rate of $\sim 20 \mathrm{~mm}$ per year between India and the Indus-Yarlung Suture (IYS) (the southern boundary of Tibet $)^{3}$, suggesting intra-plate shortening has to accommodate the velocity differences. Existing magnetic, paleomagnetic and volumetric balancing studies estimate that India-Eurasia convergence varies along the Himalayan arc, increasing from $1,800 \mathrm{~km}$ in the west to $2,800 \mathrm{~km}$ in the east ${ }^{4}$. Lithospheric processes that accommodate the total convergence have been widely speculated upon. Hypotheses include the following, potentially co-existing, scenarios: wholesale underthusting of the Indian plate beneath the plateau, underthrusting in the south with lower-crustal flow beneath the central and northern plateau ${ }^{6,7}$, distributed shortening and thickening of the Tibetan $\mathrm{crust}^{8}$, northward injection of the Indian crust $^{9}$, convective removal of the lower portion of thickened Tibetan lithosphere $(\mathrm{TL})^{10}$, indentation by a rigid Indian plate and continental block extrusion ${ }^{11,12}$ and intracontinental subduction from the India and/or the Asia side $\mathrm{s}^{13,14}$

Surface-observation-based geodetic, geologic and tectonic studies often focus on the convergence budget of crustal lithosphere ${ }^{15}$. In contrast to well-agreed upon crustal thickening, direct evidence for thickening of the underlying lithospheric mantle has, thus far, been lacking. As such, the question of how continental mantle lithosphere is consumed beneath Tibet and its role in Tibetan tectonic evolution remains open $^{13}$. Seismic tomographic images can map the geometry and spatial extent of mantle lithosphere in terms of high wave speed anomalies and shed light on Tibetan tectonic evolution ${ }^{16,17}$. However, differences among existing seismic images complicate the interpretation of mantle lithospheric process. For example, such processes under Central and Eastern Tibet are still heavily debated, and include underplating ${ }^{5,18}$, highangle subduction ${ }^{19-21}$, horizontal extrusion ${ }^{17}$ and distributed thickening together with subsequent convective removal ${ }^{22}$. Resolutions to these outstanding debates rely on more robust seismic observations of mantle lithosphere beneath Tibet, constraining, for example, the northern extent and convergence angle of Indian lithosphere (IL).

Discrepancies among previous tomographic studies are due to the following main causes, namely differences in station coverage or seismic phase information used in the inversion and different underlying theories such as the ray, normal mode and finitefrequency theories. The latest method developed for seismic

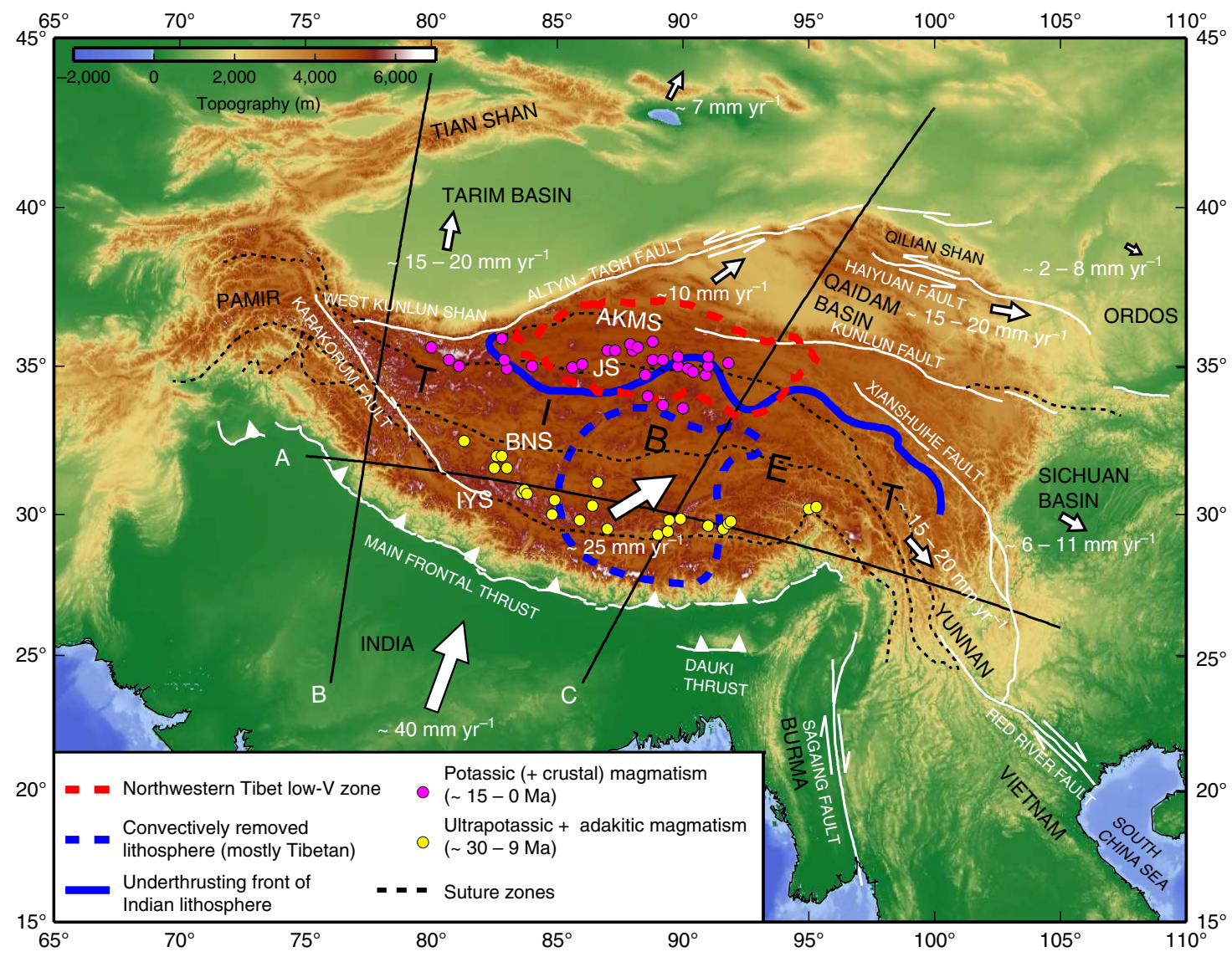

Figure 1 | Geological map of Tibet and surrounding regions. Major fault traces (white lines) and suture zones (black dash lines) are obtained from the HimaTibetMap-1.1 data set ${ }^{69}$. Yellow and magenta filled circles mark two different episodes of magmatism distributions ${ }^{46,53}$. White arrows indicate motions of different tectonic units relative to stable Eurasia 2,70 . The thick red dashed line delineates the $-4 \%$ contour of shear wave speed anomalies $\left(\delta \ln V_{S}\right)$ at a depth of $80 \mathrm{~km}$ beneath Northern Tibet, the thick blue line denotes the $2 \%$ contour of $\delta \ln V_{\mathrm{S}}$ at a depth of $175 \mathrm{~km}$ and the thick blue dashed line represents the $2 \%$ contour of $\delta \ln V_{S}$ at a depth of $350 \mathrm{~km}$. All the contour lines are extracted from Fig. 2a-c. The abbreviations of suture zones, IYS, BNS, JS and AKMS are defined in Fig. 4. 
tomography, called adjoint tomography, accounts for off-ray path three-dimensional (3-D) sensitivity, takes advantage of multiple seismic phases that sense different parts of the earth, and therefore improves the accuracy of mapping elastic properties of Earth's interior from seismic records ${ }^{23}$. Here we use adjoint tomography (see the 'Methods' section for details), based on a spectral-element method (SEM) and 3-D finite-frequency sensitivity kernels to assimilate full waveform informationincluding (but not limited to) $\mathrm{P}$ and $\mathrm{S}$ body waves and Love and Rayleigh surface waves recorded by a wide-aperture dense arrayto obtain a new seismic model named EARA2014 (ref. 24). Details of the model construction and its quality assessment are provided in a previous publication ${ }^{24}$.

The goal of this study is to interpret observed shear wave speed anomalies in the upper mantle as they relate to the post-collision fate of Indian, Tibetan and Asian mantle lithospheres, and to better understand the connection between lithospheric evolution and surface expressions of plateau uplift and volcanism (Fig. 1). We attribute a T-shaped high wave speed (high-V) structure beneath South-Central Tibet to lithospheric foundering during the Oligocene, which causes surface major uplift and ultrapotassic and adakitic magmatism in Southern Tibet. Overriding the foundering lithosphere, high-V IL underthrusts Tibet as far north as the Jinsha Suture (JS) at present. A narrow low wave speed zone imaged in the uppermost mantle beneath Northern Tibet, consistent with recent potassic volcanism, suggests that surface uplift of Northern Tibet is subject to more recent asthenospheric upwelling and thermal erosion of thickened lithosphere.

\section{Results}

Mantle tomography. Mantle shear wave speed anomalies in model EARA2014 vary distinctly across Tibet in both S-N and W-E directions (Figs 2-4). For convenience, we define that Southern and Northern Tibet are separated by the JS, which approximately coincides with the $2 \%$ level contour of shear wave speed anomalies at a depth of $175 \mathrm{~km}$ (Figs 1 and 2b). We also define that Southern Tibet is divided into three sub-regions from west to east, namely Southwestern, South-Central and Southeastern Tibet, at longitudes of $83^{\circ} \mathrm{E}$ and $92^{\circ} \mathrm{E}$ based on the $3-\mathrm{D}$ contour surface of $2 \%$ shear wave speed anomalies (Figs $3 \mathrm{~b}$ and 5a). Two prominent high- $\mathrm{V}$ structures are identified in the mantle: a sub-horizontal high-V structure just below the Moho down to a depth of $250 \mathrm{~km}$ consistently imaged along the Himalayan arc (Figs 3b,c and 5a) and a T-shaped high-V structure beneath South-Central Tibet extending from $250 \mathrm{~km}$ depth to the bottom of the transition zone (Fig. 4e). The strongest low wave speed (low-V) anomalies within Tibet are located in the crust and uppermost mantle in a narrow $\mathrm{W}-\mathrm{E}$ oriented zone about $200 \mathrm{~km}$ wide (Figs 1,2a,4e and 5b,c). This low-V zone follows the JS from longitude $83^{\circ} \mathrm{E}$ to longitude $95^{\circ} \mathrm{E}$ and is approximately bounded by the Anymaqen-Kunlun-Muztagh Suture to its north (Fig. 5b,c). The shear wave speeds inside this low- $\mathrm{V}$ zone exhibit more than $4 \%$ reductions in the uppermost mantle and more than $6 \%$ reductions in the crust.

Compared with traditional tomographic methods which heavily rely on 'crustal corrections', adjoint tomography ${ }^{25}$ has the advantage of incorporating 3-D crustal structure in the initial model and iteratively updating it with both body- and surfacewaveform information, thereby effectively minimizing crustal contamination of the mantle in the final images. The high-V structures at different depths in the upper mantle are well resolved in our study under South-Central Tibet (see the 'Methods' section for details; Supplementary Fig. 1). Resolution tests show that high-V perturbations at both 150 and $400 \mathrm{~km}$ depths can be recovered (Supplementary Fig. 1). The upper
$250 \mathrm{~km}$ of shear wave speeds in the crust and uppermost mantle (Figs 2a,b,3 and 4) especially have improved resolution compared with most of the global or regional tomographic models based on asymptotic methods and 'crustal corrections' (for example, Supplementary Fig. 2, their Figs 7 and 9 in ref. 24). The low-V zone in Northern Tibet is well constrained by both body and surface waves and is laterally more confined along the JS compared to previous results based solely on surface waves ${ }^{26}$ or $\mathrm{Pn}$ and $\mathrm{Sn}$ waves $^{27-29}$. On the other hand, the observed low- $\mathrm{V}$ zone in this study is a broadened vertical feature throughout the crust and uppermost mantle due to the lack of very high-frequency waves in our inversion (Supplementary Fig. 1a,b). More robust recovery of the amplitude and depth extent of the low- $\mathrm{V}$ anomalies within the crust requires the incorporation of shorter period surface waves $(<20 \mathrm{~s})$ and body waves $(<12 \mathrm{~s})$, and more regional crustal earthquake data. We will leave discussions of mid-lower crustal flow related low- $\mathrm{V}$ anomalies for future full waveform inversion studies and will focus on interpreting the low- $\mathrm{V}$ imprint in the uppermost mantle.

\section{Discussion}

We interpret the sub-horizontal high-V structure ( $>2 \%$ increases) shallower than $250 \mathrm{~km}$ in the mantle as IL underthrusting beneath Tibet. The thickness of the underthrusting IL is between 100 and $150 \mathrm{~km}$ based on the $2 \%$ level contour of shear wave speed anomalies (Figs 3 and 4). This observation is consistent with a receiver-function study of the interfaces beneath the Indian subcontinent ${ }^{30}$, where the derived depths of the lithosphere-asthenosphere boundary vary between 70 and $140 \mathrm{~km}$, and reach up to $\sim 170 \mathrm{~km}$ beneath the Himalayan region and Moho depths located between 30 and $56 \mathrm{~km}$. Arc-normal cross-sections $\mathrm{B}$ and $\mathrm{C}$ show that underthrusting IL gently dips northward at an angle of $\sim 10^{\circ}$ (Fig. $4 \mathrm{~b}, \mathrm{e}$ ) without visible high-angle subduction in the deeper upper mantle. It is laterally continuous from the Main Frontal Thrust to its northern leading edge, which proceeds beyond the Bangong-Nujiang Suture (BNS) and as far north as the JS (Figs 1,2b and 4, and Supplementary Fig. 2a-d). Our interpreted location of IL's leading edge (Fig. 1), approximately coinciding with the JS, is different from previous interpretations from $\mathrm{P}$-wave models based on traditional tomographic methods. P-wave tomography studies generally map the IL underthrusting/subduction front ${ }^{19,31-34}$ very close to (for example, Supplementary Fig. 2f) or to the south of the BNS (for example, Supplementary Fig. 2g,h) in Central Tibet between $87^{\circ} \mathrm{E}$ and $91^{\circ} \mathrm{E}$. Along profile $83^{\circ} \mathrm{E}$, a model comparison (Supplementary Fig. 2a,e) shows agreement on that the IL underthrusting front reaches as far north as JS in both model EARA2014 and the global P-wave model used in Replumaz et al. ${ }^{32}$ However, their P-wave model ${ }^{32}$ reveals a much thicker $(\sim 300 \mathrm{~km}$ thick) craton-like structure beneath India (Supplementary Fig. 2e), whereas EARA2014 shows a normal thickness of $\sim 150 \mathrm{~km}$ without invoking underthrusting a very thick continental craton.

Seismicity is distributed along the interpreted upper interface of IL and terminates at depths shallower than $\sim 100 \mathrm{~km}$ (Fig. 4c,f). Except along profile B, one earthquake at a depth of $140 \mathrm{~km}$ located by the EHB catalogue ${ }^{35}$ (event ID: 12477266) occurs in the vicinity of the interpreted IL upper interface (Fig. 4c). There is a large gap between this deep earthquake and shallower crustal seismicity along the interface of IL. Therefore, it probably belongs to the southward subducting Pamir slab, annotated as Asian lithosphere (AL) (Fig. 4c). It is possible that the IL upper interface is steeper under Himalayan blocks between the Main Frontal Thrust and the IYS ${ }^{36}$ and flattens further 

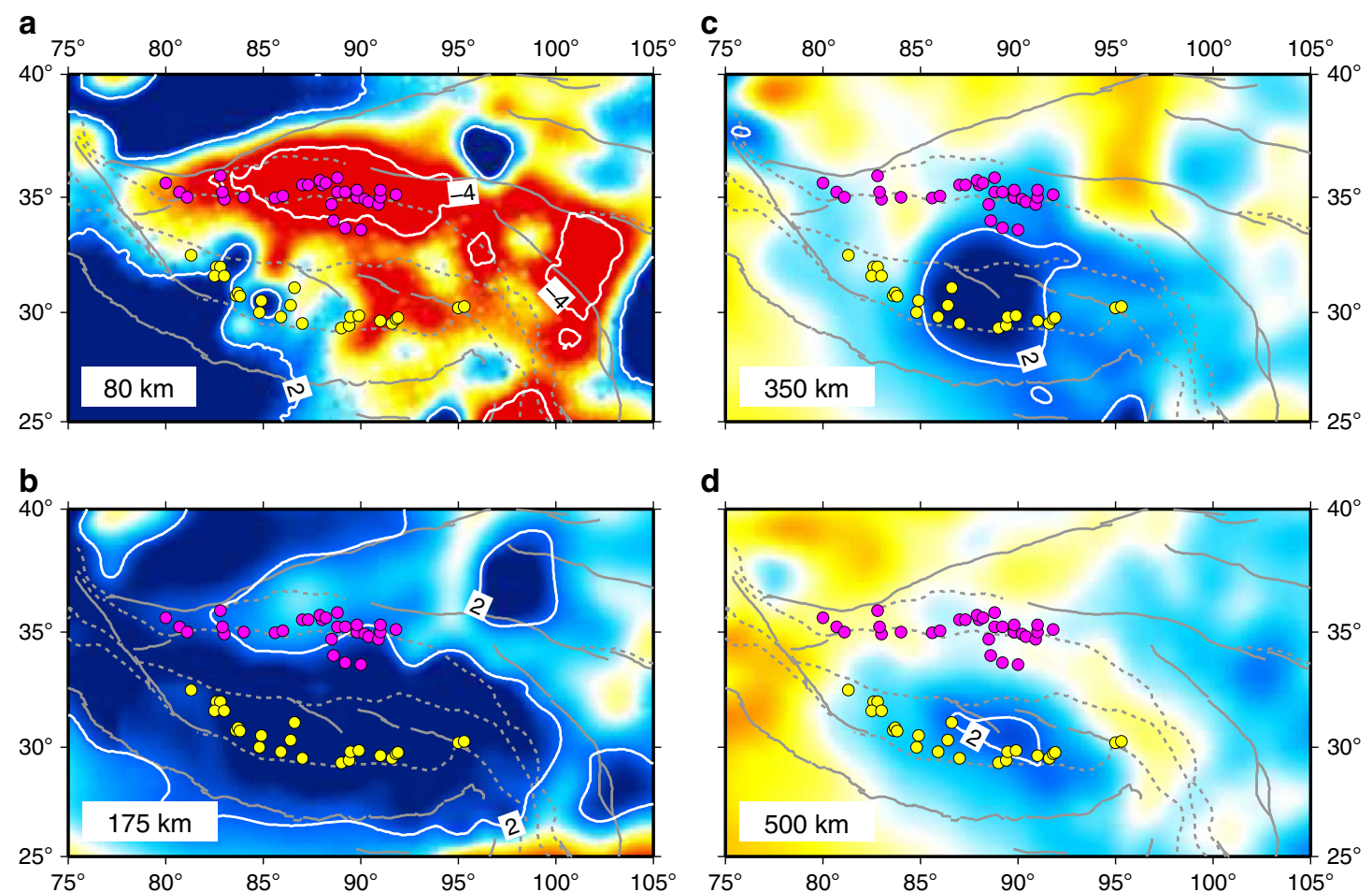

d

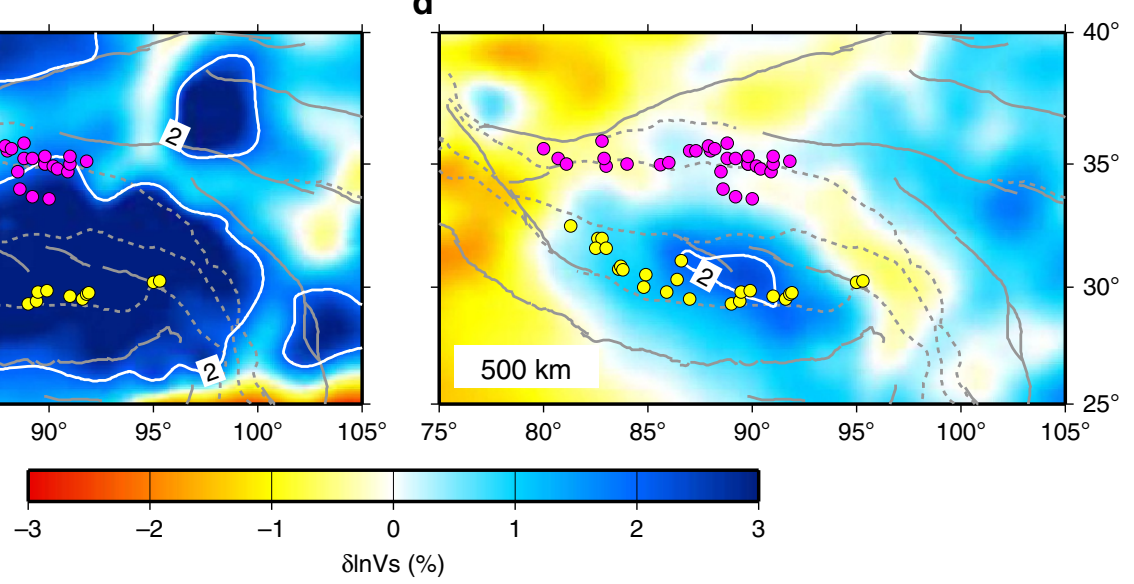

Figure 2 | Shear wave speed anomalies at different depths. Map views at (a) $80 \mathrm{~km}$, (b) $175 \mathrm{~km}$, (c) $350 \mathrm{~km}$ and (d) $500 \mathrm{~km}$ depth. Major fault traces and suture zones are delineated in grey solid lines and grey dashed lines respectively. Yellow and magenta filled circles mark two different episodes of magmatism distribution (Fig. 1). White lines delineate -4 and $2 \%$ contours of $\delta \ln V_{s}$.

north $^{37}$, but such details cannot be resolved in this study due to resolution limits.

No large-scale low- $\mathrm{V}$ anomalies are discernable within the underthrusting IL, which does not support the hypotheses of IL being fragmented due to delamination and asthenosphere upwelling ${ }^{20,21}$. Low-V anomalies beneath Southern Tibet are only visible at depths shallower than $150 \mathrm{~km}$. Such low-V anomalies (more than $2 \%$ reductions) imply possible partial melting. The low-V zones located at crust and uppermost mantle depths do not have a visible connection to any deeper mantle low- $\mathrm{V}$ zones. This suggests that partial melting is not a mantle driven process, but instead a crustal process either related to shear heating generated in ductile shear zones near the India-Himalaya lithospheric interface ${ }^{38}$ or to radioactive heating within the crust $^{39}$.

Lateral heterogeneities do exist within the interpreted IL in the arc-parallel direction, where beneath the Southern Tibet rift region $\left(83^{\circ} \mathrm{E}-95^{\circ} \mathrm{E}\right) \sim 200 \mathrm{~km}$ wide strongly high-V zones (more than $4 \%$ increases) alternate with $\sim 100 \mathrm{~km}$ wide relatively weakly high- $\mathrm{V}$ zones (3-4\% increases) (Fig. 3c). This suggests that underthrusting IL is probably intact, with local weaker zones representing either pre-existing, that is, before initial subduction, structures or locally modified regions due to melt and/or volatile injection after subduction. Absolute values of shear wave speeds in the underthrusting region range from 4.7 to $4.8 \mathrm{~km} \mathrm{~s}^{-1}$ (Figs $3 \mathrm{c}$ and $4 \mathrm{c}, \mathrm{f}$, and Supplementary Figs 3 and 4), comparable to those of the North American craton and much higher than in active tectonic regions $\left(<4.5 \mathrm{~km} \mathrm{~s}^{-1}\right)$ in the uppermost mantle ${ }^{40}$. If the underthrusting IL can be treated as the root of the present-day TL, then the lithospheric structure of Tibet resembles that of Archaean and Proterozoic cratons, except with a hotter and thicker crust at present, which may be gradually eroded at the top and become more similar in terms of crustal thickness to Archaean and Proterozoic cratons ${ }^{39}$.

Underlying underthrusting IL, the T-shaped high-V structure beneath South-Central Tibet has a less obvious origin (Figs $4 \mathrm{e}$ and $6 \mathrm{~d}$ ). Its top part is located above the transition zone with a height of about $150 \mathrm{~km}$ and an arc-normal width of $\sim 750 \mathrm{~km}$ spanning from latitude $28^{\circ} \mathrm{N}$ (south of the IYS) to latitude $33^{\circ} \mathrm{N}$ (north of the BNS). Its bottom part resides in the transition zone with a height of $\sim 250 \mathrm{~km}$ and an arc-normal width of $\sim 200 \mathrm{~km}$, situated between the IYS and BNS. In contrast to a narrow high-V structure observed from a depth of $250 \mathrm{~km}$ to the top of the transition zone beneath Western Pacific regions (for example, the Japan and Izu-Bonin convergent margins), which is associated with abundant deep-focus seismicity and interpreted as subducting oceanic lithosphere ${ }^{24}$, the deep mantle high-V structure beneath South-Central Tibet is a much broader feature and completely lacks seismicity. Such striking differences indicate that the T-shaped high-V structure is unlikely subducting oceanic lithosphere and the portion of Indian oceanic lithosphere probably already sank into the lower mantle ${ }^{16,32,41,42}$. This argument is further bolstered by a simple estimation of the total budget of consumed continental lithosphere after complete subduction of Indian oceanic lithosphere. The total budget of continental lithosphere, possibly from Indian, Tibetan, or Asian continental blocks, that entered the mantle since continental collision is conservatively estimated at $\sim 2,250 \mathrm{~km}$ in length, given an average convergence rate of $50 \mathrm{~mm}$ per year since $45 \mathrm{Ma}^{1}$. However, the observed IL overriding the T-shaped high-V structure is $\sim 750 \mathrm{~km}$ in length (Fig. $6 \mathrm{~d}$ ), which accounts for only one-third of the total budget and leaves the remaining $\sim 1,500 \mathrm{~km}$ unaccounted for. If the imaged T-shaped high-V 


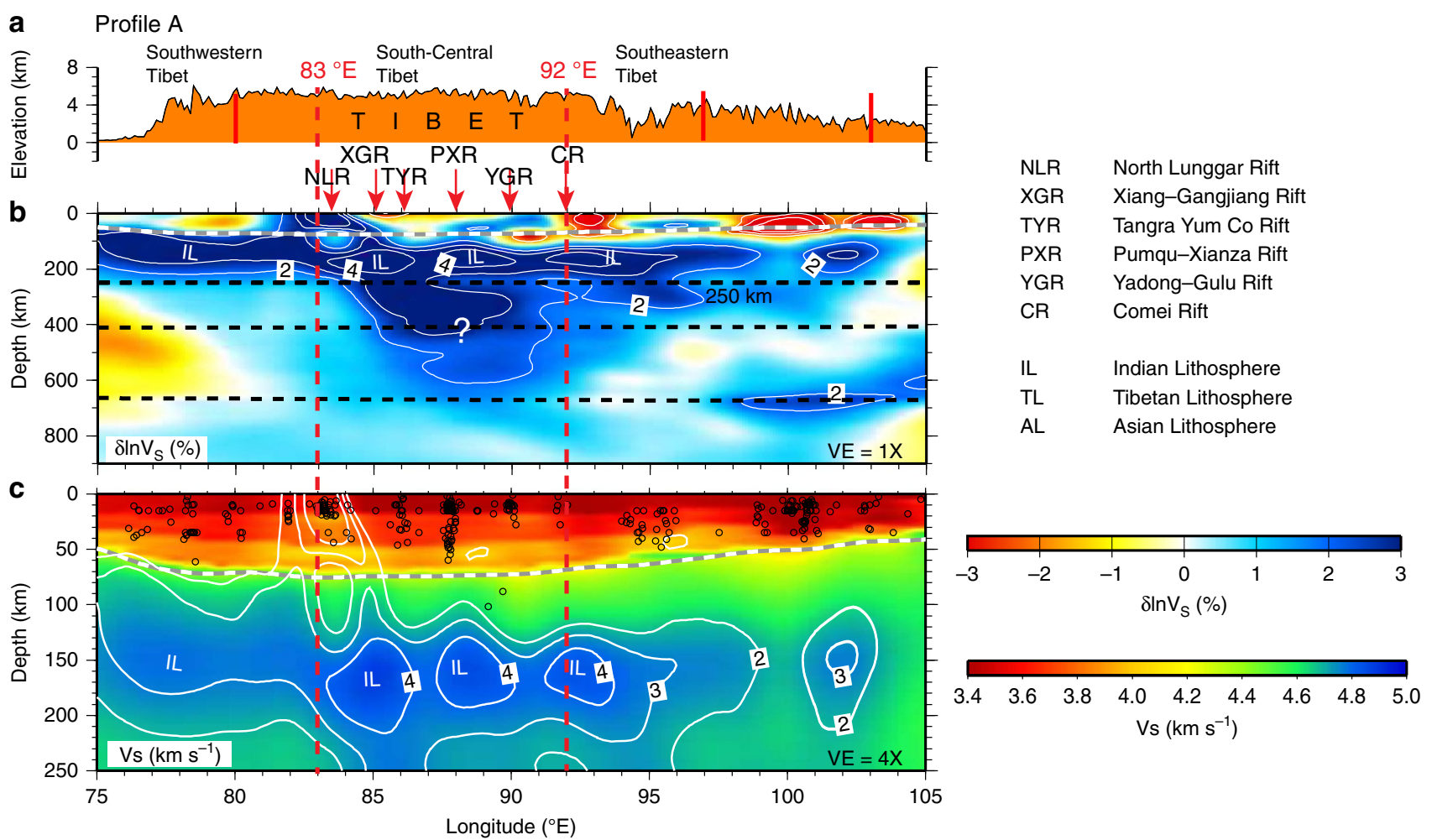

Figure 3 | Cross-sections showing surface elevations and seismic structures along an arc-parallel profile. (a) The surface elevations, (b) shear wave speed anomalies $\left(\delta \ln V_{S}\right)$ and $(\mathbf{c})$ shear wave speeds $\left(V_{S}\right)$ along profile A (Fig. 1). In b, black dashed lines mark a depth of $250 \mathrm{~km}$ and the 410 and 660 discontinuities, and white lines represent $\delta \ln V_{S}$ contour levels from -4 to $-2 \%$ and from 2 to $4 \%$ at $1 \%$ intervals. In $\mathbf{c}$, black circles denote the seismicity, $V_{S}$ are plotted with $4 \times$ of vertical exaggeration $(V E=4 \times)$, and white lines represent $\delta \ln V_{S}$ contour levels from 2 to $4 \%$ at $1 \%$ intervals extracted from $\mathbf{b}$. In $\mathbf{b}$ and $\mathbf{c}$, grey dashed line delineates the Moho from CRUST2.0 (ref. 25). The abbreviations of rift zones, NLR, XGR, TYR, PXR, YGR and CR, and the different lithospheric block, IL, TL and AL are defined in the text block on the right.

structure is interpreted as a foundering continental mantle lithosphere, that is, the majority of the thickened continental mantle lithosphere detached at the bottom but with some part of the top portion still left attached to the crust above, then unwrapping the area of the imaged anomaly to a $120 \mathrm{~km}^{30}$ thick pre-collision lithosphere gives a length estimate of about $1,354 \mathrm{~km}$ (equation 1 and Fig. 6d),

$$
\text { Length }=(750 \times 150+200 \times 250) / 120=1354(\mathrm{~km})
$$

which makes up the majority of the missing post-collision continental lithosphere. Therefore we argue that the T-shaped high- $\mathrm{V}$ structure is of continental lithospheric origin.

It is still yet to be determined if the detached T-shaped lithosphere is derived from Indian, Tibetan, or Asian continental blocks, because all three continental blocks have the possibility of entering and remaining in the upper mantle through different processes, such as subduction followed by slab breakoff ${ }^{16}$, or lithospheric thickening followed by convective removal ${ }^{43}$, that is, foundering in this discussion. If AL subducts southwards under Tibet and later breaks off, a south dipping slab structure would be expected under Northern Tibet from either the Tarim or Qaidam Basins. A previous receiver-function study images a prominent south-dipping interface down to $250 \mathrm{~km}$ beneath northern Tibet and interprets it as the top of south dipping $\mathrm{AL}^{44}$. However, there is no compatible seismic tomographic evidence showing positive wave speed jumps downward across the imaged interface (for example, their Fig. 4 in a previous $\mathrm{P}$-wave tomography study ${ }^{42}$ ). Alternatively, the receiver-function interpreted south dipping AL interface ${ }^{44,45}$ can be reconciled with the strong wave speed contrast between our interpreted weakly high-V TL and the strongly low-V zone above (Fig. 4e), which we speculate as an internal interface within TL. Moreover, consistent with previous tomographic results ${ }^{20,21}$, no obvious evidence of south dipping AL under Northern Tibet is shown in the arc-normal cross-section (Fig. 4e), because weakly high-V anomalies $(<1 \%$ increase) interpreted as TL are significantly weaker than strongly high- $\mathrm{V}$ anomalies (2 to $5 \%$ increases) interpreted as $\mathrm{AL}$. In the $\mathrm{W}-\mathrm{E}$ oriented cross section along latitude $36^{\circ} \mathrm{N}, \mathrm{AL}$ is also outlined by strong high-V anomalies of 2 to $5 \%$ down to a depth of at least $250 \mathrm{~km}$ under the Qilian Shan fold-thrust belt and is seismically discernible from TL that has weakly high-V anomalies of less than 1\% (Supplementary Fig. 5). Although our observation does not support the model involving AL southward subduction leading to growth of crustal accretionary wedges ${ }^{12,13}$, it is possible that AL subducts eastward at a dip angle of $\sim 25^{\circ}$ from the Qaidam Basin and contributed to the high-elevation of the Qilian Shan fold-thrust belt (Supplementary Fig. 5).

Therefore, continental lithosphere more likely foundered from IL or TL or both, although their relative contributions depend on the pre-collision thickness and strength of both lithospheric blocks. As TL is considered to be hotter and, as result, most likely to be rheologically weaker than colder $\mathrm{IL}^{46}$, we speculate that Tibetan mantle lithosphere is more prone to thicken along with the crust right after continental collision starts (Fig. 6a). The colder and stronger Indian mantle lithosphere is more likely to undergo underthrusting without significant internal deformation. Continued penetration of IL is resisted by thickened TL and is likely to be limited to a few hundred kilometers of distance in the arc-normal direction (Fig. 6a). Owing to the Rayleigh-Taylor instability ${ }^{43,47}$, the viscous lower part of thickened Tibetan mantle lithosphere can initially 'drip' 

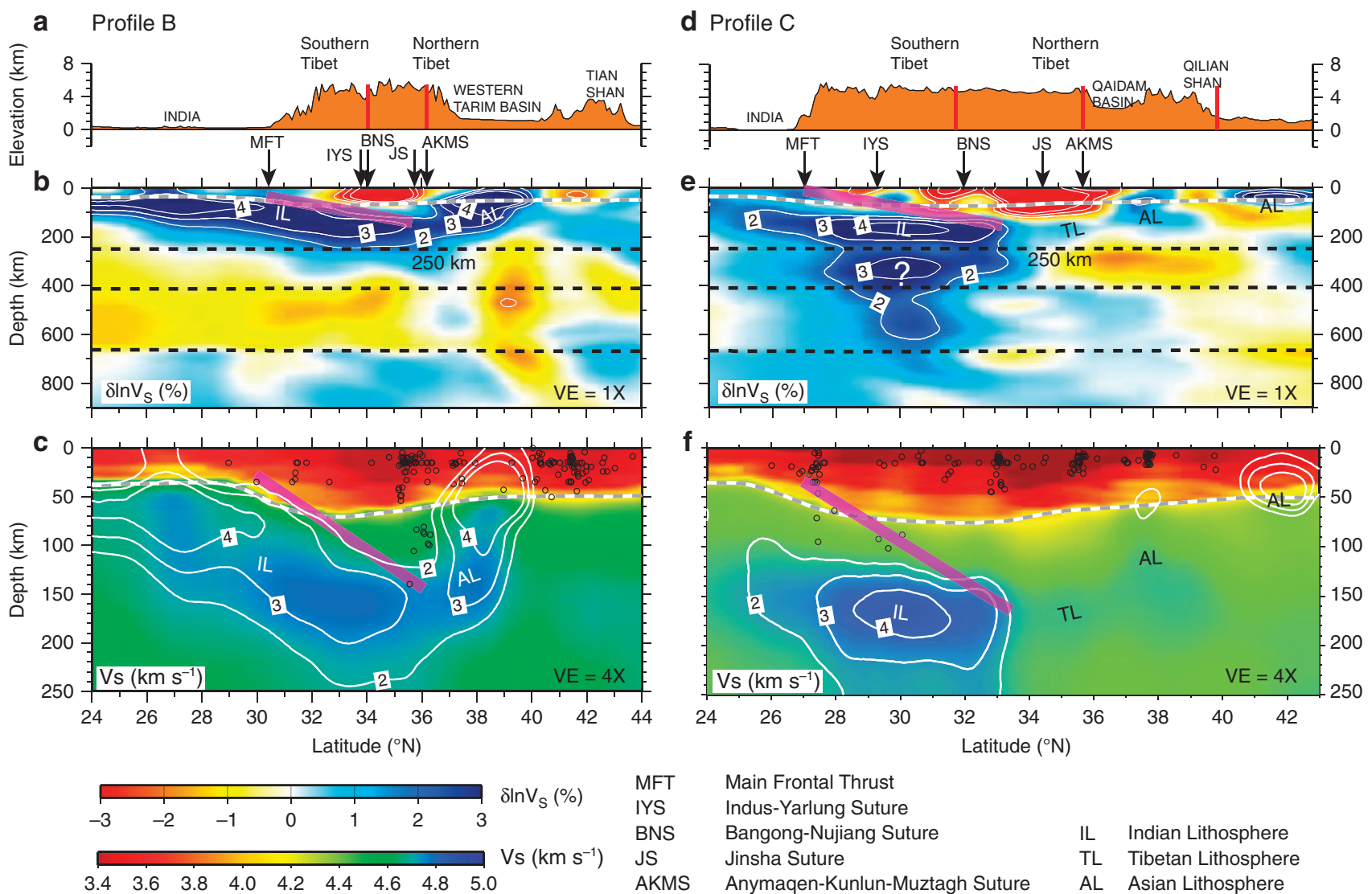

MFT
IYS
BNS
JS
AKMS

Main Frontal Thrust

Indus-Yarlung Suture

Bangong-Nujiang Suture

Jinsha Suture

Anymaqen-Kunlun-Muztagh Suture

\section{IL Indian Lithosphere \\ TL Tibetan Lithosphere \\ AL Asian Lithosphere}

Figure 4 | Cross-sections showing surface elevations and seismic structures along arc-normal profiles. (a) The surface elevations, (b) shear wave speed anomalies $\left(\delta \ln V_{S}\right)$ and $(\mathbf{c})$ shear wave speeds $\left(V_{S}\right)$ along profile B (Fig. 1). (d) The surface elevations, (e) $\delta \ln V_{S}$ and (f) $V_{S}$ along profile $C($ Fig. 1$)$. In a and $\mathbf{d}$, vertical red bars indicate major fault zones. In $\mathbf{b}$ and $\mathbf{e}$, black arrows mark the Main Frontal Thrust (MFT) and suture zones (IYS, BNS, JS and AKMS) and white lines represent $\delta \ln V_{\mathrm{S}}$ contour levels from -4 to $-2 \%$ and from 2 to $4 \%$ at $1 \%$ intervals. In c and $\mathbf{f}$, black circles denote the seismicity, $V_{S}$ are plotted with $4 \times$ of vertical exaggeration $(V E=4 \times$ ), black dashed lines mark a depth of $250 \mathrm{~km}$ and the 410 and 660 discontinuities, and white lines represent $\delta \ln V_{\mathrm{S}}$ contour levels from 2 to $4 \%$ at $1 \%$ intervals extracted from $\mathbf{b}$ and $\mathbf{e}$, respectively. In $\mathbf{b}, \mathbf{c}, \mathbf{e}$ and $\mathbf{f}$, grey dashed lines delineate the Moho from CRUST2.0 (ref. 25) and thick magenta lines represent the interpreted upper interface of underplated IL with a dip angle of $10^{\circ}$.

on a relatively small scale ( $\sim 200 \mathrm{~km}$ wide), followed by breakoff of the more rigid upper part $(\sim 750 \mathrm{~km}$ wide $)$ of IL and TL accommodated by faults or other weak zones ${ }^{47}$.

The timing of lithospheric foundering beneath Southern Tibet can be constrained by the timing of ultrapotassic and adakitic magmatism that initiates at about $\sim 30 \mathrm{Ma}$ and lasts until $\sim 9 \mathrm{Ma}$ (Figs 1 and $6 \mathrm{a}-\mathrm{c})^{46}$. Post-collision adakitic magmatism suggests the occurrence of thickening of TL and subsequent lithospheric root foundering. Lithospheric foundering significantly thinned Southern TL that was thickened before $30 \mathrm{Ma}$ due to continental collision. The loss of lithospheric root can drive surface uplift during the Oligocene ${ }^{48}$ and observed ultrapotassic and adakitic magmatism, fueled by the ascent of asthenospheric return flow. The continued sinking of foundering lithosphere in the upper mantle can also generate lateral pressure gradients in viscous asthenosphere that can drive shear traction at the base of overlying mantle lithosphere ${ }^{49}$. This shear traction drives northward underthrusting of IL and thickening of remaining TL in the north (Fig. 6b-d). The northward advance of underthrusting IL gradually shuts off sources of heat and melting and causes waning of ultrapotassic and adakitic magmatism in Southern Tibet ${ }^{46}$.

We conclude that the leading edge of IL has moved northwards over an arc-normal distance of about $750 \mathrm{~km}$ (Figs $4 \mathrm{e}$ and 6d) since the acceleration of underthrusting at $\sim 25 \mathrm{Ma}$ (Fig. $6 \mathrm{~b}$ ), when the lower part of the pre-thickened lithosphere becomes detached completely. This interpretation gives an estimated average underthrusting rate of about $30 \mathrm{~mm}$ per year in the past 25 million years. It is slightly higher than the current ongoing convergence rate of $\sim 20 \mathrm{~mm}$ per year between India and the IYS, but remains a reasonable estimate as convergence is expected to have slowed down due to resistance associated with thickened lithosphere ${ }^{50}$.

Northern TL is probably being heated by asthenospheric upwelling. The S-N contrast in shear wave speed perturbations in our model (Supplementary Fig. 3) is compatible with other results independent from seismic tomography. Based on our observed $3 \%$ of S-N $V_{S}$ difference and a relation between $V_{S}$ perturbation and temperature of $1.3 \pm 0.30 \%$ per $100 \mathrm{~K}$ at $200 \mathrm{~km}^{51}$, TL under Northern Tibet is estimated to be $200-300 \mathrm{~K}$ warmer than underthrusting IL beneath Southern Tibet. Such temperature difference in the uppermost mantle agrees with heat flow modelling ${ }^{52}$. The S-N difference of the average shear wave speed between the surface and $410 \mathrm{~km}$ depth (about $3 \%$ along profile D; Supplementary Fig. 3) is also consistent with receiver function observations of the 410- and 660-discontinuities being parallel and relatively depressed in the south ${ }^{44}$. Thickened Northern TL may be gradually eroded or thermally modified by hot asthenospheric upwelling (Fig. 6c,d). The good spatial correlation between the strongly low- $\mathrm{V}$ zone in the uppermost mantle and more recent potassic magmatism in Northern Tibet $(\sim 15-0 \mathrm{Ma})^{46,53}$ (Figs 1,5b,c and $6 \mathrm{c}, \mathrm{d}$ ) further support the 


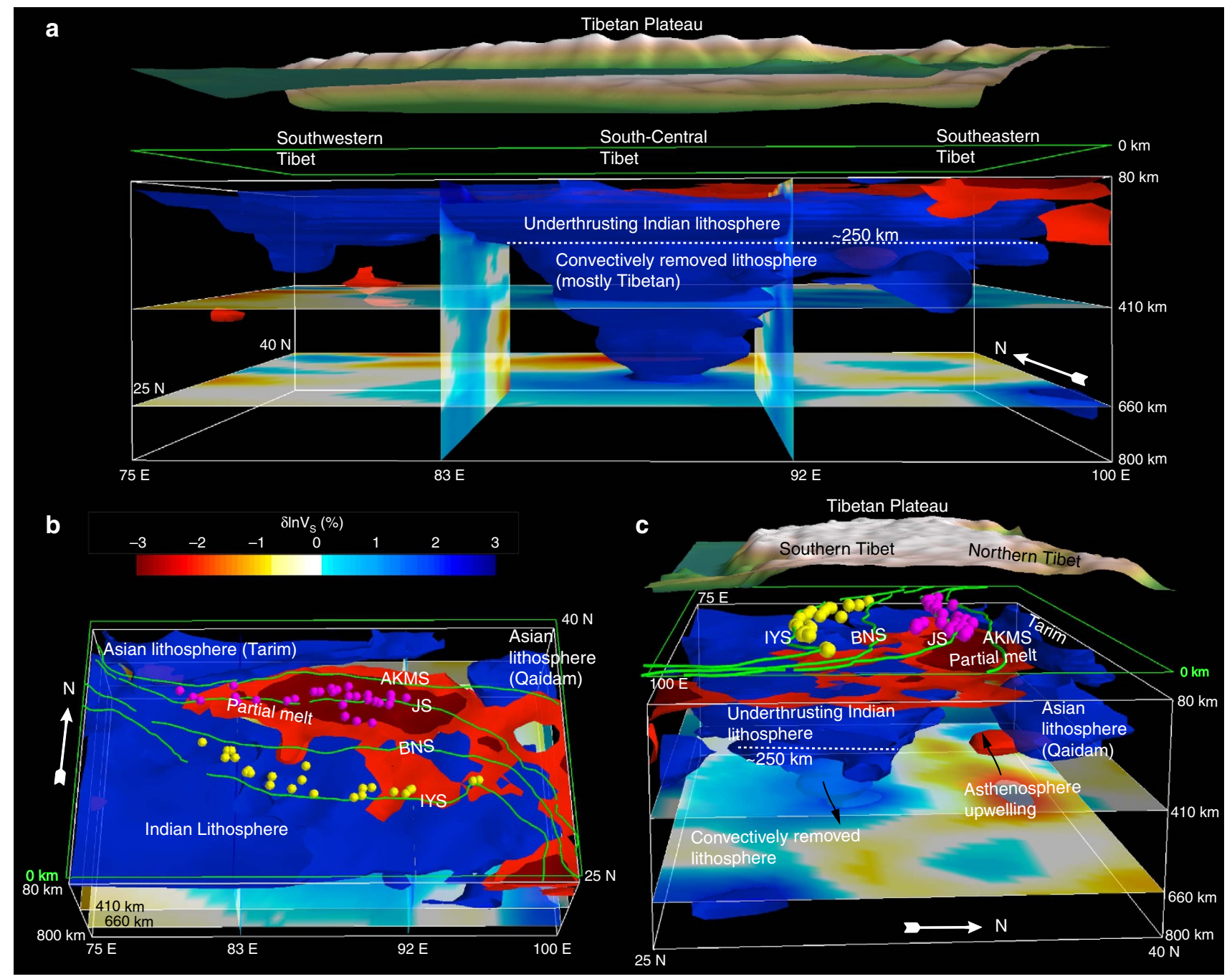

Figure 5 | Three-dimensional visualization of the shear wave speed structure under the Tibetan Plateau. The $-4 \%$ (dark red), $-2 \%$ (red) and $2 \%$ (blue) isosurfaces of $\delta \ln V_{S}$ are rendered from EARA2014 (ref. 24). Green lines mark the four suture zones IYS, BNS, JS, and AKMS. For reference, four planes showing variations of $\delta \ln V_{\mathrm{S}}$ are cut at depths of 410 and $660 \mathrm{~km}$, and along longitudes $83^{\circ} \mathrm{E}$ and $92^{\circ} \mathrm{E}$. (a) The geometry of Indian (blue) and Asian (blue) lithospheres and the distribution of possible partial melt (dark red) are viewed upward from the south, (b) downward from the south and (c) from the east.

hypothesis of asthenospheric upwelling. The low-V anomalies are, however, limited to the uppermost mantle $(<125 \mathrm{~km})$ overlying weakly high-V TL that extends down to a depth of $\sim 200 \mathrm{~km}$. Contrary to more dramatic lithospheric foundering and thinning during the Oligocene in Southern Tibet, Northern TL more likely to be experienced 'diffused' root removal or thermal modification and is still largely intact. Thermal modification can lead to a more buoyant lithospheric mantle that isostatically supports uplift of Northern Tibet.

Our results are consistent with the following conceptual model. Distributed thickening of TL and underthrusting of IL accommodate the bulk of mantle lithosphere convergence since India-Eurasia collision. Convergence leads to shortening and thickening of $\mathrm{TL}$, including both crust and mantle. Subsequent foundering of thickened lithosphere during the Oligocene contributed to the rise of Southern Tibet. The foundering lithosphere is continental in origin and, as a result, is less negatively buoyant than oceanic lithosphere. This can lead to a long residence time $(\sim 30 \mathrm{Ma})$ of foundering continental lithosphere in the upper mantle. In addition, the 660-discontinuity can act as rheological and density barrier preventing foundering continental lithosphere from sinking into the lower mantle (Fig. 6d).
Different from pure subduction settings, where lithosphere subducts without much thickening, the India-Eurasia continental collision zone involves thickening of the continental mantle lithosphere (TL) and low-angle underthrusting of stronger IL. Deformation and thickening on the Tibetan side is not confined to the crust and is more vertically distributed throughout the entire column of crustal and mantle lithosphere. Wholesale thickening of TL can initiate a Rayleigh-Taylor instability and subsequent foundering (convective removal) of the lithospheric root. Convective removal and associated lithospheric foundering creates an additional plate driving force, an asthenospheric drag force, resulting in continued thrusting of IL under Tibet. This is different from the principal driving force of plate tectonics at oceanic subduction zones, which is created by negative buoyancy of dense oceanic mantle lithosphere. The direct impact of such convective removal is a more pulsed surface uplift of Southern Tibet over a time scale of $<10$ m.y. $(\sim 30-25 \mathrm{Ma})$ rather than over the entire $45 \mathrm{~m} . \mathrm{y}$. of India-Eurasia collision.

If northward penetration of IL slows down exponentially due to resistance from viscous mantle lithosphere ${ }^{50}$, it is likely to be that India-Tibet convergence will terminate by the time IL occupies the entire uppermost mantle underneath Tibet. 

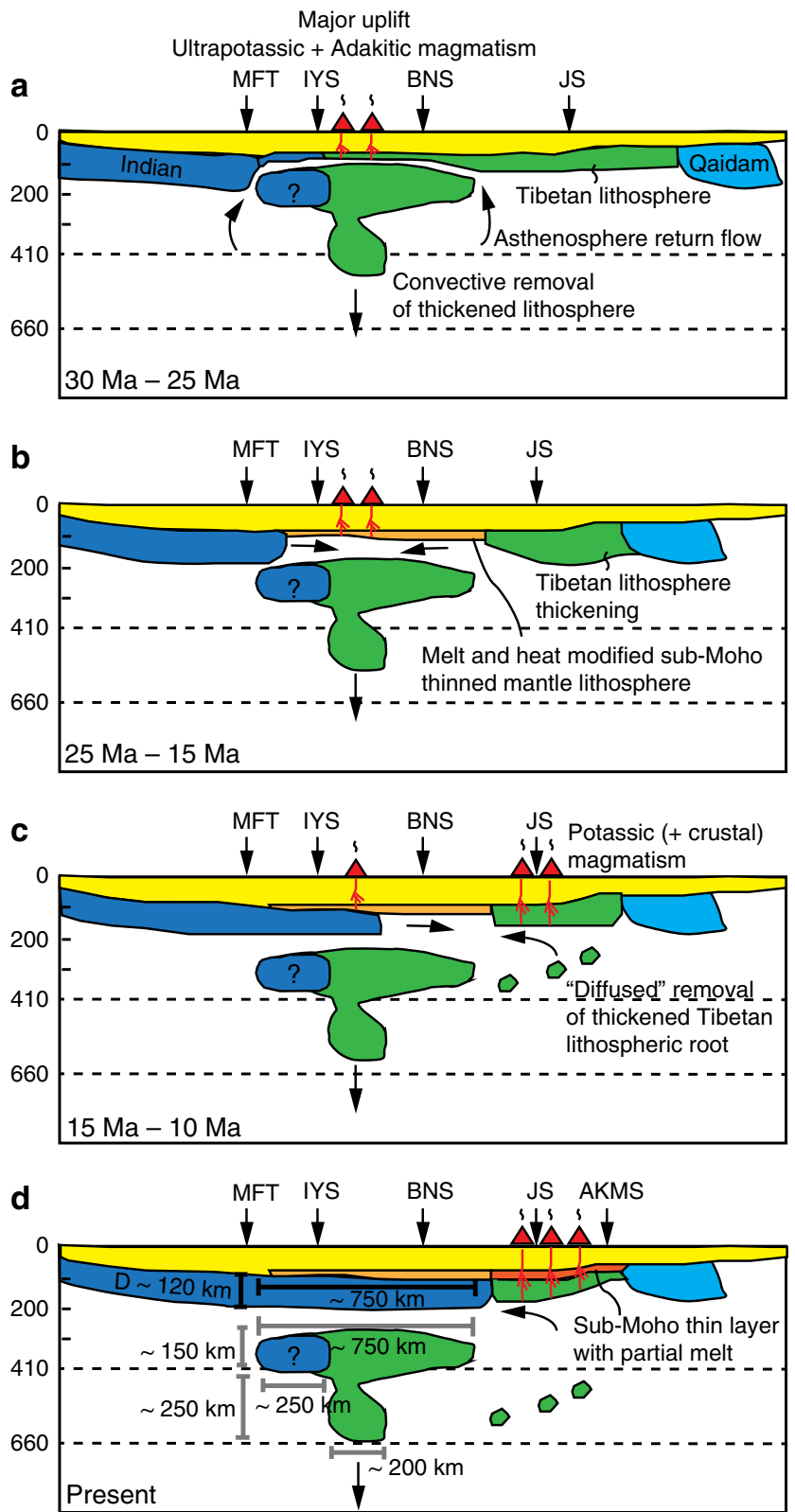

Figure 6 | Inferred tectonic evolution of Tibet. The interpretation is based on the seismic image along profile $\mathrm{C}$ (Fig. $4 \mathrm{e}$ ) as well as previous studies on magmatism ${ }^{46,53}$. (a) Between $30 \mathrm{Ma}$ and $25 \mathrm{Ma}$ : following lithospheric thickening due to continental collision, convective instability triggers removal of a lithosphere root and surface uplift. Asthenospheric return flow initiates ultrapotassic and adakitic volcanism in Southern Tibet. (b) Between $25 \mathrm{Ma}$ and $15 \mathrm{Ma}$ : magmatism persists in Southern Tibet while partial melt and heat modify the remaining thin uppermost mantle lithosphere. (c) Between $15 \mathrm{Ma}$ and $10 \mathrm{Ma}$ : further northward underthrusting of IL gradually shuts down the heat source of magmatism in Southern Tibet. (d) Present: Southern Tibet is completely underthrusted by IL up to the south of the JS. Magmatism in Northern Tibet is still an ongoing process.

The strength and buoyancy of Indian continental lithosphere might keep it in place beneath Tibet for a substantial amount of time, possibly long enough to be considered the root of a stable craton. This might provide a mechanism for the formation of a modern craton in the Tibet-Himalaya continental collision margin, consistent with geodynamic modeling ${ }^{54}$ and similar to a previously proposed mechanism of craton formation through underthrusting and imbrication of oceanic lithosphere ${ }^{55}$, however, through under-accretion of Indian continental lithosphere instead.

\section{Methods}

Adjoint tomography and model construction. Seismic images of Tibet and its surrounding regions are rendered from East Asia Radially Anisotropic Model (EARA2014) ${ }^{24}$. This structural model is developed using adjoint tomography, assimilating 1.7 million frequency-dependent traveltime measurements from waveforms of 227 earthquakes recorded by 1,869 stations in East Asia. The majority of stations are from the CEArray ${ }^{56}$ densely covering China. Tibet has complementary station coverage from INDEPTH (International Deep Profiling of Tibet and the Himalaya) IV two-dimensional broadband deployment and other regional and global arrays. Adjoint tomography in this application utilizes a highly accurate SEM to simulate 3-D seismic wave propagation ${ }^{57,58}$ and to calculate finite-frequency sensitivity kernels for iterative tomographic inversion ${ }^{59-61}$. Technical details of model construction are described in a previous publication ${ }^{24}$ Here we briefly summarize the data and method. Our initial model consists of a 3-D global radially anisotropic mantle model S362ANI ${ }^{62}$ and a 3-D crustal model Crust2. $0^{25}$. Initial earthquake source parameters are described by the centroid moment-tensor (CMT) solution ${ }^{63}$. A total of 227 earthquakes $(\mathrm{Mw}=5-7)$ with good signal-to-noise-ratio records are selected from the global CMT solution database. Source parameters are reinverted using CMT3D inversion method ${ }^{64}$ with synthetic waveforms simulated in the initial 3-D structural model on global scale. Seismic waveforms from five high-quality global and regional seismic networks (IU, II, G, GE and IC) are used in the source inversion to insure good global azimuthal coverage. Observed and synthetic waveforms are bandpass filtered in three complementary period bands, namely, from 30 to $60 \mathrm{~s}, 50$ to $100 \mathrm{~s}$ and 80 to $150 \mathrm{~s}$. Body wave misfits in the period range $30-60 \mathrm{~s}$ and body wave and surface wave misfits in 50-100 s and 80-150 s passbands are used in the source inversions. After the source inversions, the subsequent iterative structural inversion takes place in a wave simulation volume described as a $80^{\circ}$ by $80^{\circ}$ spherical chunk laterally centered on China and vertically spanning from the surface to Earth's core. All the used earthquakes and stations are contained in the model simulation volume. Our regional 3-D models have an isotropic parameterization in the crust and in the mantle below the transition zone, and a radially anisotropic parameterization between the Moho and the $660 \mathrm{~km}$ discontinuity. The SEM mesh incorporates a 4-min topography model created by subsampling and smoothing ETOPO-2 (ref. 65), as well as undulations of the $\mathrm{Moho}^{25}$, and the 410 and $660 \mathrm{~km}$ discontinuities ${ }^{62}$. We updated the 3-D regional structure based on finite-frequency kernels with fixed source parameters. Our data set for structural inversion consists of three-component waveforms recorded by 1,869 stations from F-net, CEArray ${ }^{56}$, NECESSArray, INDEPTH IV Array and other regional and global seismic Networks. The regional structural model is parameterized on the SEM Gauss-Lobatto-Legendre integration points, which have an $8 \mathrm{~km}$ lateral spacing and a vertical spacing of $<5 \mathrm{~km}$ in the crust, and a $16 \mathrm{~km}$ lateral spacing and an average vertical spacing of $\sim 10 \mathrm{~km}$ in the upper mantle. Synthetic seismograms for the initial 3-D model and subsequent updated models were calculated for all stations. Measurement windows are selected in three passbands, namely $15-40 \mathrm{~s}$, $30-60 \mathrm{~s}$ and $50-100 \mathrm{~s}$ for the first 12 iterations. In subsequent iterations we lowered the lower bounds of these passbands to 12,20 and 40 s, respectively. Selecting measurement windows is accomplished based on FLEXWIN ${ }^{66}$, an algorithm to automatically pick measurement windows in vertical, radial and tangential component seismograms by comparing observed and synthetic seismograms. Frequency-dependent traveltime misfits are measured within the chosen windows. Adjoint sources are constructed using traveltime misfit measurements for all picked phases, for example, body wave phases (direct P and S, pP, sP, sS, pS, PP and SS) and surface waves (Rayleigh and Love). The adjoint sources assimilate the misfit as simultaneous fictitious sources, and the interaction of the resulting adjoint wavefield with the regular forward wavefield forms the event kernels. All event kernels are summed to obtain the gradient or Fréchet derivative, which is preconditioned and smoothed for a conjugate gradient model update. The optimal step length for the model update is chosen based on a line search. The updated model is used as the starting model for the next iteration of further structural refinement. The same procedure is repeated until no significant reduction in misfit is observed, in our case after 20 iterations.

Resolution test. Model quality of EARA2014 is extensively assessed by examining waveform misfit reductions, establishing regions with reasonably good data coverage, comparing with previous tomographic models, performing resolution tests at several locations of interest, and an inversion with a different initial model. For details of model quality assessment please refer to previous publication ${ }^{24}$ Here we focus on 'point-spread function' (PSF) resolution tests targeting the uppermost mantle and mid-upper mantle high-V Indian lithospheric structure beneath South-Central Tibet. The PSF test evaluates the resolution of a particular point of interest in the model by the degree of 'blurring' of a perturbation located at that point, and by revealing the tradeoff with other model parameters ${ }^{67,68}$. We placed a spherical anomaly represented by 3 -D Gaussian functions centered at two different depths, $150 \mathrm{~km}$ (uppermost mantle) and $400 \mathrm{~km}$ (mid-upper mantle) beneath South-Central Tibet, with a $120 \mathrm{~km}$ radius and a maximum of $4 \%$ 
perturbation in $V_{\mathrm{SV}}$ (Supplementary Fig. 1a,c). Although there is certain degree of smearing (Supplementary Fig. 1b,d), $V_{S V}$ PSFs at both depths recover the main features of the perturbations. On the other hand, our resolution tests (Supplementary Fig. 1) also suggest that the T-shaped feature at deeper depth (250 km and deeper) might be artificially mapped about $50 \mathrm{~km}$ upwards (Supplementary Fig. 1c,d) due to the vertical smearing effect of body wave resolution at this depth range.

Model analysis. Tibetan upper mantle has relatively higher wave speeds compared with the rest of East Asia in model EARA2014 (ref. 24). The regional mean of shear wave speeds at each depth is calculated for a region spanning from $65^{\circ} \mathrm{E}$ to $120^{\circ} \mathrm{E}$ and $20^{\circ} \mathrm{N}$ to $45^{\circ} \mathrm{N}$ (Supplementary Fig. 3). In the seismic images (Figs $2-4$ and Supplementary Fig. 5) and 3-D visualizations (Fig. 5), the regional mean at each depth has been removed and converted to percentage perturbations to emphasize wave speed variations in Tibet and surrounding regions.

Data availability. Digital file of model EARA2014 in the study region of this manuscript is available upon request to the corresponding author.

\section{References}

1. Lee, T.-Y. \& Lawver, L. A. Cenozoic plate reconstruction of Southeast Asia. Tectonophysics 251, 85-138 (1995).

2. Gan, W. et al. Present-day crustal motion within the Tibetan Plateau inferred from GPS measurements. J. Geophys. Res. 112, B08416 (2007).

3. Bilham, R., Larson, K. \& Freymueller, J. GPS measurements of present-day convergence across the Nepal Himalaya. Nature 386, 61-64 (1997).

4. Johnson, M. R. W. Shortening budgets and the role of continental subduction during the India-Asia collision. Earth Sci. Rev. 59, 101-123 (2002).

5. Zhou, H. W. \& Murphy, M. A. Tomographic evidence for wholesale underthrusting of India beneath the entire Tibetan plateau. J. Asian Earth Sci. 25, 445-457 (2005)

6. Royden, L. H. Surface deformation and lower crustal flow in Eastern Tibet. Science 276, 788-790 (1997).

7. Owens, T. J. \& Zandt, G. Implications of crustal property variations for models of Tibetan plateau evolution. Nature 387, 37-43 (1997).

8. Houseman, G. \& England, P. Finite strain calculations of continental deformation. II-Comparison with the India-Asia collision zone. J. Geophys. Res. 91, 3664-3676 (1986).

9. Zhao, W.-L. \& Morgan, W. J. Injection of Indian crust into Tibetan lower crust: a two-dimensional finite element model study. Tectonics 6, 489-504 (1987).

10. England, P. \& Houseman, G. Extension during continental convergence, with application to the Tibetan plateau. J. Geophys. Res. 94, 17561-17579 (1989).

11. Tapponnier, P., Peltzer, G., Dain, A. Y., Le, Armijo, R. \& Cobbold, P. Propagating extrusion tectonics in Asia: new insights from simple experiments with plasticine. Geology 10, 611-616 (1982).

12. Tapponnier, P. et al. Oblique stepwise rise and growth of the Tibet plateau. Science 294, 1671-1677 (2001).

13. Willett, S. D. \& Beaumont, C. Subduction of Asian lithospheric mantle beneath Tibet inferred from models of continental collision. Nature 369, 642-645 (1994).

14. Roger, F. et al. An Eocene magmatic belt across central Tibet: mantle subduction triggered by the Indian collision? Terra Nova 12, 102-108 (2000).

15. DeCelles, P. G., Robinson, D. M. \& Zandt, G. Implications of shortening in the Himalayan fold-thrust belt for uplift of the Tibetan Plateau. Tectonics 21, 1062-1073 (2002).

16. Replumaz, A., Negredo, A. M., Villaseñor, A. \& Guillot, S. Indian continental subduction and slab break-off during Tertiary collision. Terra Nov 22, 290-296 (2010).

17. Replumaz, A., Negredo, A. M., Guillot, S. \& Villaseñor, A. Multiple episodes of continental subduction during India/Asia convergence: insight from seismic tomography and tectonic reconstruction. Tectonophysics 483, 125-134 (2010).

18. Priestley, K., Debayle, E., McKenzie, D. \& Pilidou, S. Upper mantle structure of eastern Asia from multimode surface waveform tomography. J. Geophys. Res. 111, B10304 (2006).

19. Tilmann, F., Ni, J. \& Team, I. I. S. Seismic imaging of the downwelling Indian lithosphere beneath central Tibet. Science 300, 1424-1427 (2003).

20. Liang, X. et al. A complex Tibetan upper mantle: a fragmented Indian slab and no south-verging subduction of Eurasian lithosphere. Earth Planet. Sci. Lett. 333-334, 101-111 (2012)

21. Nunn, C., Roecker, S. W., Priestley, K. F., Liang, X. \& Gilligan, A. Joint inversion of surface waves and teleseismic body waves across the Tibetan collision zone: the fate of subducted Indian lithosphere. Geophys. J. Int. 198, 1526-1542 (2014).

22. Ren, Y. \& Shen, Y. Finite frequency tomography in southeastern Tibet: evidence for the causal relationship between mantle lithosphere delamination and the north-south trending rifts. J. Geophys. Res. 113, B10316 (2008).
23. Liu, Q. \& Gu, Y. J. Seismic imaging: from classical to adjoint tomography. Tectonophysics 566-567, 31-66 (2012).

24. Chen, M., Niu, F., Liu, Q., Tromp, J. \& Zhen, X. Multiparameter adjoint tomography of the crust and upper mantle beneath East Asia: 1. Model construction and comparisons. J. Geophys. Res. 120, 1762-1786 (2015).

25. Bassin, C., Laske, G. \& Masters, G. The current limits of resolution for surface wave tomography in North America. EOS Trans. AGU 81, F897 (2000).

26. Yang, Y. et al. A synoptic view of the distribution and connectivity of the mid-crustal low velocity zone beneath Tibet. J. Geophys. Res. 117, B04303 (2012).

27. McNamara, D. E., Walter, W. R., Owens, T. J. \& Ammon, C. J. Upper mantle velocity structure beneath the Tibetan Plateau from Pn travel time tomography. J. Geophys. Res. 102, 493-505 (1997).

28. McNamara, D. E., Owens, T. J. \& Walter, W. R. Observations of regional phase propagation across the Tibetan Plateau. J. Geophys. Res. 100, 22215-22229 (1995).

29. Barron, J. \& Priestley, K. Observations of frequency-dependent Sn propagation in Northern Tibet. Geophys. J. Int. 179, 475-488 (2009).

30. Kumar, P. et al. Imaging the lithosphere-asthenosphere boundary of the Indian plate using converted wave techniques. J. Geophys. Res. 118, 5307-5319 (2013).

31. Li, C., van der Hilst, R. D., Meltzer, A. S. \& Engdahl, E. R. Subduction of the Indian lithosphere beneath the Tibetan Plateau and Burma. Earth Planet. Sci. Lett. 274, 157-168 (2008).

32. Replumaz, A., Capitanio, F. A., Guillot, S., Negredo, A. M. \& Villaseñor, A. The coupling of Indian subduction and Asian continental tectonics. Gondwana Res. 26, 608-626 (2014)

33. Obayashi, M. et al. Finite frequency whole mantle $\mathrm{P}$ wave tomography: Improvement of subducted slab images. Geophys. Res. Lett. 40, 5652-5657 (2013).

34. Wei, W., Xu, J., Zhao, D. \& Shi, Y. East Asia mantle tomography: new insight into plate subduction and intraplate volcanism. J. Asian Earth Sci. 60, 88-103 (2012).

35. Engdahl, E. R., van der Hilst, R. \& Buland, R. Global teleseismic earthquake relocation with improved travel times and procedures for depth determination. Bull. Seismol. Soc. Am. 88, 722-743 (1998).

36. Ni, J. \& Barazangi, M. Seismotectonics of the Himalayan Collision Zone: geometry of the underthrusting Indian Plate beneath the Himalaya. J. Geophys. Res. 89, 1147-1163 (1984).

37. Nábelek, J. et al. Underplating in the Himalaya-Tibet collision zone revealed by the Hi-CLIMB experiment. Science 325, 1371-1374 (2009).

38. Nabelek, P. I., Whittington, A. G. \& Hofmeister, A. M. Strain heating as a mechanism for partial melting and ultrahigh temperature metamorphism in convergent orogens: implications of temperature-dependent thermal diffusivity and rheology. J. Geophys. Res. 115, B12417 (2010).

39. McKenzie, D. \& Priestley, K. Speculations on the formation of cratons and cratonic basins. Earth Planet. Sci. Lett. 435, 94-104 (2016).

40. Grand, S. P. \& Helmberger, D. V. Upper mantle shear structure of North America. Geophys. J. R. Astron. Soc. 76, 399-438 (1984).

41. Van der Voo, R., Spakman, W. \& Bijwaard, H. Tethyan subducted slabs under India. Earth Planet. Sci. Lett. 171, 7-20 (1999).

42. Replumaz, A., Guillot, S., Villaseñor, A. \& Negredo, A. M. Amount of Asian lithospheric mantle subducted during the India/Asia collision. Gondwana Res. 24, 936-945 (2013).

43. England, P. C. \& Houseman, G. A. The mechanics of the Tibetan Plateau. Philos. Trans. R. Soc. A 326, 301-320 (1988).

44. Kind, R. et al. seismic images of crust and upper mantle beneath Tibet: Evidence for Eurasian Plate subduction. Science 298, 1219-1221 (2002).

45. Zhao, W. et al. Tibetan plate overriding the Asian plate in central and northern Tibet. Nat. Geosci. 4, 870-873 (2011).

46. Chung, S. L. et al. The nature and timing of crustal thickening in Southern Tibet: geochemical and zircon Hf isotopic constraints from postcollisional adakites. Tectonophysics 477, 36-48 (2009).

47. Pysklywec, R. N., Beaumont, C. \& Fullsack, P. Modeling the behavior of the continental mantle lithosphere during plate convergence. Geology 28, 655-658 (2000).

48. Wei, Y. et al. Low palaeoelevation of the northern Lhasa terrane during late Eocene: fossil foraminifera and stable isotope evidence from the Gerze Basin. Sci. Rep. 6, 27508 (2016).

49. Alvarez, W. Protracted continental collisions argue for continental plates driven by basal traction. Earth Planet. Sci. Lett. 296, 434-442 (2010).

50. Clark, M. K. Continental collision slowing due to viscous mantle lithosphere rather than topography. Nature 483, 74-77 (2012)

51. Cammarano, F., Goes, S., Vacher, P. \& Giardini, D. Inferring upper-mantle temperatures from seismic velocities. Phys. Earth Planet. Inter 138, 197-222 (2003).

52. Jiménez-Munt, I., Fernàndez, M., Vergés, J. \& Platt, J. P. Lithosphere structure underneath the Tibetan Plateau inferred from elevation, gravity and geoid anomalies. Earth Planet. Sci. Lett. 267, 276-289 (2008). 
53. Chung, S. L. et al. Tibetan tectonic evolution inferred from spatial and temporal variations in post-collisional magmatism. Earth Sci. Rev. 68, 173-196 (2005).

54. Cooper, C. M., Lenardic, A., Levander, A. \& Moresi, L. Creation and preservation of Cratonic lithosphere: seismic constraints and geodynamic models. Archean Geodyn. Environ. Geophys. Monogr. Ser. 164, 75-88 (2013).

55. Lee, C.-T. a., Luffi, P. \& Chin, E. J. Building and destroying continental mantle. Annu. Rev. Earth Planet. Sci. 39, 59-90 (2011).

56. Zheng, X. et al. Technical system construction of data backup centre for china seismograph network and the data support to researches on the Wenchuan earthquake. Chinese J. Geophys. (in Chinese) 52, 1412-1417 (2009).

57. Komatitsch, D. \& Tromp, J. Spectral-element simulations of global seismic wave propagation-I. Validation. Geophys. J. Int. 149, 390-412 (2002).

58. Komatitsch, D. \& Tromp, J. Spectral-element simulations of global seismic wave propagation-II. Three-dimensional models, oceans, rotation and self-gravitation. Geophys. J. Int. 150, 303-318 (2002).

59. Tromp, J., Tape, C. \& Liu, Q. Seismic tomography, adjoint methods, time reversal and banana-doughnut kernels. Geophys. J. Int. 160, 195-216 (2005).

60. Liu, Q. \& Tromp, J. Finite-frequency sensitivity kernels for global seismic wave propagation based upon adjoint methods. Geophys. J. Int. 174, 265-286 (2008).

61. Zhu, H., Bozdağ, E., Peter, D. \& Tromp, J. Seismic wavespeed images across the Iapetus and Tornquist suture zones. Geophys. Res. Lett. 39, L18304 (2012).

62. Kustowski, B., Ekström, G. \& Dziewoński, A. M. Anisotropic shear-wave velocity structure of the Earth's mantle: a global model. J. Geophys. Res. 113, B06306 (2008).

63. Ekström, G., Dziewoński, A. M., Maternovskaya, N. N. \& Nettles, M. Global seismicity of 2003: centroid-moment-tensor solutions for 1087 earthquakes. Phys. Earth Planet. Int. 148, 327-351 (2005).

64. Liu, Q., Polet, J., Komatitsch, D. \& Tromp, J. Spectral-element moment tensor inversions for earthquakes in Southern California. Bull. Seismol. Soc. Am. 94, 1748-1761 (2004).

65. National Geophysical Data Center. 2-Minute Gridded Global Relief Data (ETOPO2v2). World Data Service for Geophysics, U.S. Department of Commerce, NOAA, Boulder, Colorado. Available at: http//www.ngdc.noaa.gov/ mgg/fliers/06mgg01.html (2006).

66. Maggi, A., Tape, C., Chen, M., Chao, D. \& Tromp, J. An automated time-window selection algorithm for seismic tomography. Geophys. J. Int. 178, 257-281 (2009).

67. Zhu, H., Bozdağ, E., Peter, D. \& Tromp, J. Structure of the European upper mantle revealed by adjoint tomography. Nat. Geosci. 5, 493-498 (2012).

68. Fichtner, A. \& Trampert, J. Hessian kernels of seismic data functionals based upon adjoint techniques. Geophys. J. Int. 185, 775-798 (2011).

69. Styron, R., Taylor, M. \& Okoronkwo, K. Database of active structures from the Indo-Asian collision. EOS Trans. Am. Geophys. Union 91, 181-182 (2010).

70. Wang, Q. et al. Present-day crustal deformation in China constrained by global positioning system measurements. Science 294, 574-577 (2001).

\section{Acknowledgements}

We thank the various networks that contributed data (F-net, CEArray, NECESSArray, INDEPTH IV Array, IRIS/IDA and other regional and global seismic networks), as well as the Rice Research Computing Support Group. The majority of waveform data were provided by the China Seismic Array Data Management Center at the Institute of Geophysics, China Earthquake Administration. We also thank Dr Anne Replumaz and another anonymous reviewer for their constructive comments and suggestions, which significantly improved the quality of this paper. This research was supported by NSF grant 1345096. This work used the Extreme Science and Engineering Discovery Environment (XSEDE), which is supported by NSF grant ACI-1053575. The open source spectral-element software package SPECFEM3D_GLOBE, the seismic measurement software package FLEXWIN and the moment-tensor inversion package CMT3D used for this article are freely available for download via the Computational Infrastructure for Geodynamics (CIG; geodynamics.org).

\section{Author contributions}

M.C. conducted the adjoint tomography and took the lead in writing the manuscript. M.C. and F.N. contributed to the data acquisition. J.T. contributed to the theory of adjoint tomography. M.C., F.N., A.L., C.-T.A.L., W.C. and J.R. contributed to the model interpretation. All authors contributed to the manuscript writing.

\section{Additional information}

Supplementary Information accompanies this paper at http://www.nature.com/ naturecommunications

Competing interests: The authors declare no competing financial interests.

Reprints and permission information is available online at http://npg.nature.com/ reprintsandpermissions/

How to cite this article: Chen, M. et al. Lithospheric foundering and underthrusting imaged beneath Tibet. Nat. Commun. 8, 15659 doi: 10.1038/ncomms15659 (2017).

Publisher's note: Springer Nature remains neutral with regard to jurisdictional claims in published maps and institutional affiliations.

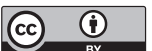

Open Access This article is licensed under a Creative Commons Attribution 4.0 International License, which permits use, sharing, adaptation, distribution and reproduction in any medium or format, as long as you give appropriate credit to the original author(s) and the source, provide a link to the Creative Commons license, and indicate if changes were made. The images or other third party material in this article are included in the article's Creative Commons license, unless indicated otherwise in a credit line to the material. If material is not included in the article's Creative Commons license and your intended use is not permitted by statutory regulation or exceeds the permitted use, you will need to obtain permission directly from the copyright holder. To view a copy of this license, visit http://creativecommons.org/ licenses/by/4.0/

(C) The Author(s) 2017 